\title{
Appendix 3: Placenames in the chronicle
}

The names of locations in South Sulawesi have been reasonably stable from the period dealt with in the chronicle until the present. That means most placenames in the chronicle can be reliably located in the modern landscape. The chief difficulty arises from the frequent use of some common descriptive names, such as Tanété, meaning a ridge or higher ground. Names are also rendered on maps with many minor variations.

Most of the peninsula is covered by two series of 1:50,000 maps. The first was produced by the Dutch topographical services between 1922 and 1934 (these maps were republished in 1943, mainly by the US Army). The second series was produced by Badan Koordinasi Survei dan Pemetaan Nasional (Bakosurtanal) Geospatial Information Agency/National Mapping Agency of Indonesia in the early 1990s. The placenames of minor villages on Map 2 have been located by reference to these two series of maps, supported by some local knowledge.

The rendition of placenames on the maps in the text follows the principle used in the translation, even when that involves some inconsistencies. Well-known names, usually of larger localities, are given in their Indonesian form; other names, usually of minor settlements, are given in their Bugis form.

The account of the reign of the third ArumPone in Chapter 3 contains groups of placenames that deserve special attention. In the following lists, those names marked with an asterisk [*] cannot be reliably identified, although often their general location is clear from the context. The remainder are shown on Map 2. 


\section{Placenames in Chapter 3}

\section{Names associated with Kerrampélua' himself}

Bone

Palakka

Paccing

Majang

Bukaka

Panyula'

Lipenno

\section{Names of the three standards}

1. Woromponong

Majang

*Mata-Anging (this might be the common name Matoanging)

Bukaka-Tengnga

Kawerrang

Palléngoreng

*Mallari

Matajang

2. Right standard

Paccing

*Tanété (a very common name)

*Lémo-Lémo

Masallé

Macégé

Bélawa

${ }^{*}$ Ciung

3. Left standard

*Araseng

Ujung

Poncéng

Ta'

*Katumpi' (the events described in the following reign suggest this is near Cina and Laliddong) 
*Padaccengnga

*Madello'

\section{Conquests of Kerrampélua'}

Palléngoreng

*Sinri

Anrobiring

Lémpang

Mellé

*Sancénreng

Cirowali

Apala

Bakke'

*Tanété

*Attassalo (this means 'south of river', but it is not clear which river is meant)

Soga

Lampoko

Lémoape'

Bulu'-Riattassalo

Parippung

*Lompu

\section{Places adopted or merged with Bone under Kerrampélua'}

Palakka

*Five territories east of the forest (the word ale', translated here as 'forest', may refer to the hilly region inland of the $100 \mathrm{~m}$ contour)

*Babauaé

Barebbo

Pattiro

Cinennung

Ureng

Pasémpe'

Kaju

Ponré

${ }^{*}$ Nine standards south of the forest

*Nine standards north of the forest 
Macknight (1983) argues the 'conquests' reflect an expansion of wet rice agriculture, while those places 'adopted' or 'merged' indicate a more general widening of power. The former lie on the plain between the Gulf of Bone and the edge of the hills, marked on Map 2 by the $100 \mathrm{~m}$ contour. The latter are either further from Bone or within the hills. 
This text is taken from The Bugis Chronicle of Bone, translated and edited by Campbell Macknight, Mukhlis Paeni and Muhlis Hadrawi, published 2020 by ANU Press, The Australian National University, Canberra, Australia.

doi.org/10.22459/BCB.2020.04 